DOI: $10.14746 / \mathrm{r} .2020 .1 .2$

\title{
Krzysztof GRZĄDZIELSKI
}

Uniwersytet im. A. Mickiewicza w Poznaniu

ORCID: 0000-0003-4823-1564

\section{Ewolucja kontroli nad mediami masowymi w kontekście tworzenia przekazu medialnego podczas wybranych konfliktów zbrojnych przed II wojną w Zatoce Perskiej}

Streszczenie: Konflikty zbrojne XX wieku stały się wydarzeniami medialnymi, a sposób w jaki dziennikarze je relacjonowali kreował w dużej mierze ich obraz w oczach społeczności międzynarodowej. Przekazy medialne stały się instrumentem oddziaływania na przebieg konfliktów oraz na decyzje wojskowych i polityków co do sposobu zarządzania mediami i informacją w czasie ich trwania. W tym kontekście, celem artykułu jest analiza ewolucji form kontroli nad mediami, ich determinantów i konsekwencji. Ukazany zostanie także wpływ tworzonych przez dziennikarzy przekazów medialnych na wybrane konflikty zbrojne. Ponadto, uwzględnione zostaną zmiany w relacjach polityków i wojskowych z przedstawicielami mediów masowych. Zakres czasowy rozważań obejmuje przykłady konfliktów, w których nastąpiły kluczowe zmiany w kontekście omawianej problematyki, począwszy od wojny w Wietnamie aż do I wojny w Zatoce Perskiej.

Słowa kluczowe: konflikt zbrojny, wojna, media, korespondent wojenny, przekaz medialny

\section{Wprowadzenie}

$\mathbf{W}$

1918 roku, podczas przemówienia w amerykańskim Senacie, senator Hiram Johnson powiedział, że ,,pierwszą ofiarą wojny jest prawda" (Pietrygała, 2014, s. 80). W kontekście zakończonych, jak i trwających konfliktów zbrojnych na świecie, stwierdzenie to wciąż pozostaje nad wyraz trafne. Wolność słowa czy swoboda działania mediów były i są mocno ograniczone w trakcie relacjonowania działań wojennych.

Wybuch konfliktu zbrojnego oraz jego zwłaszcza początkowa faza może zawsze liczyć na szeroką relacje medialną. Wojny i konflikty stały się bowiem wydarzeniami, których nie mogą pominąć media masowe 
w swoich programach. Często możemy oglądać poruszające lub drastyczne zdjęcia tworzone przez dziennikarzy, naocznych świadków wydarzeń czy uczestników - strony konfliktu. Ze względu, iż tematyka wojenna jest atrakcyjna dla odbiorców mediów, również siły zbrojne stron walczących wpływają na media masowe w celu osiągnięcia własnych korzyści (Bednarek, 2018, s. 31-40). Relacje medialne z konfliktów potrafią też skłonić polityków, bezpośrednio lub pośrednio przez presję społeczną, do przedsięwzięcia działań dyplomatycznych czy militarnych. Nie da się bowiem nie zauważyć, że konflikty zbrojne XX wieku stały się wydarzeniami medialnymi, a sposób w jaki dziennikarze je relacjonowali kreował w dużej mierze ich obraz w oczach społeczności międzynarodowej. Zaangażowanie mediów stworzyło bowiem sytuację, w której informacja staje się instrumentem oddziaływania, mającym istotny wpływ na przebieg samego konfliktu, jak i jego obraz (Klepka, 2016, s. 7-9). Wobec powyższego, celem artykułu jest ukazanie ewolucji form kontroli nad mediami, ich determinantów i konsekwencji, a także wskazanie wpływu mediów masowych oraz tworzonego przez dziennikarzy przekazu medialnego na wybrane konflikty zbrojne. Ponadto, przedstawione zostaną zmiany w relacjach polityków i wojskowych z przedstawicielami mediów masowych. Zakres czasowy rozważań obejmuje, w warstwie analizy historycznej, wybrane przykłady konfliktów, w których nastąpiły kluczowe zmiany w kontekście omawianej problematyki, od wojny w Wietnamie w latach 1955-1975 aż do 1991 roku - operacji „Pustynna Burza” podczas I wojny w Zatoce Perskiej. Przedstawiony zostanie także istotny kontekst rozwoju relacji politycy-wojsko-dziennikarze przed wojną w Wietnamie. Niemniej, omówienie kolejnych studiów przypadku pozwoli pokazać jak realizowano poszczególne modele relacji, a także na jakie zmiany i udoskonalenia decydowali się decydenci wojskowi oraz rządzący. Cezura wietnamskiej wojny i I wojny w Zatoce Perskiej ma swoje uzasadnienie ze względu na przełomowe w dziennikarstwie wojennym sposoby zarządzania mediami podczas tych konfliktów ${ }^{1}$. Natomiast jeśli chodzi o zakres przestrzenny pracy, ze względu na znaczący udział amerykańskich sił zbrojnych w omawianych konfliktach, postanowiono skupić się na analizie amerykańskich, tradycyjnych mediów masowych, tamtejszej opinii publicznej, jak i relacji w triadzie politycy-wojsko-dziennikarze.

${ }^{1}$ Doświadczenia zebrane podczas I wojny w Zatoce Perskiej miały znaczący wpływ na relacje władza-wojsko-dziennikarze podczas II wojny w Zatoce Perskiej i wprowadzony wówczas model ,dziennikarstwa skoszarowanego" (ang. embedded journalism). 
Prezentowany artykuł jest próbą odpowiedzi na następujące pytania badawcze. W jakim zakresie przebiegała ewolucja kontroli nad mediami stosowana przez wojskowych oraz władze USA? Jak zmieniał się w historii zakres cenzury stosowanej wobec korespondentów wojennych i jaki miało to wpływ na rzetelność przekazu medialnego? W jaki sposób relacje medialne o wojnie wpływają na decyzje polityków, działania armii czy na stosunek opinii publicznej co do konfliktu zbrojnego?

\section{Historyczne aspekty relacji politycy-wojsko-dziennikarze podczas konfliktów zbrojnych}

Rozważania Karla von Clausewitza, pruskiego generała i teoretyka wojny, uznawane są za teoretyczną podstawę uzasadniania wprowadzania cenzury oraz kontroli nad informacją wojenną. Po rewolucji francuskiej podkreślił on, że wojna przestała być już sprawą zawodowych żołnierzy i polityków, a stała się sprawą całych narodów. Jego zdaniem opinię publiczną należało mobilizować i wyzwalać w niej siłę oporu. Każda wojna powinna uwzględniać trzy czynniki: rząd definiujący jej cele, armię, która o te cele walczy oraz naród, który je popiera (Kunczik, Zipfel, 2000, s. 270-271).

W ujęciu historycznym dla korespondencji wojennej przełomowa była wojna krymska w 1853 roku. Wcześniej na obszar konfliktów wysyłano byłych lub obecnych wojskowych. Wówczas zaś redakcja „The Times" postanowiła na Krym wysłać cywila - Williama Howarda Russela. W literaturze przedmiotu jest on uznawany za pierwszego, prawdziwego korespondenta wojennego. Relacje z toczącej się wojny wysyłał w formie listów. Dzięki niemu, po raz pierwszy, brytyjscy czytelnicy mogli zapoznać się z prawdziwym obrazem toczącej się wojny, a nie jedynie oficjalnymi komunikatami dowództwa (Ibidem, s. 268-269). Dziennikarz opisywał przebieg bitew podczas krymskiej kampanii, jak i warunki w jakich umierali żołnierze. Po ujawnieniu szeregu popełnianych przez dowódców błędów oraz informacji, że trzy czwarte armii zmarło na cholerę i od mrozu, rząd Jerzego Aberdeena w 1855 roku zmuszony był podać się do dymisji (Grochmalski, 2001, s. 153).

W USA znaczący rozwój korespondencji wojennej nastąpił w połowie XIX wieku, wraz z rozkwitem taniej, brukowej prasy masowej nazwanej „prasą groszową” (ang. penny press). Gdy w 1898 roku rozpoczął się amerykańsko-kubański konflikt zbrojny uczestniczyło w nim pół tysiąca 
amerykańskich dziennikarzy. Czołowe pisma osiągnęły gigantyczne jak na owe czasy nakłady, a wydawcy przekonali się, że materiały prasowe z frontu wojny bardzo dobrze się sprzedają. Obok ilustratorów wojennych, na masową skalę, pojawili się fotoreporterzy (Ibidem, s. 154-155).

W czasie I wojny światowej większość państw biorących w niej udział rozpoczęła prowadzenie wojny propagandowej. Celem była nie tylko kompromitacja przeciwnika, ale także przekonanie własnych społeczeństw co do zasadności wzięcia w niej udziału. Stanowiło to swoiste novum. Rządzący uświadomili sobie, że prasa jest istotnym instrumentem kształtowania opinii publicznej. Pełniła ona funkcję nie tylko informatora, ale przede wszystkim narzędzia propagandowego oddziaływującego na społeczeństwo (Pękasa, 2008, s. 165). Pojawiły się też pierwsze kroniki filmowe z frontu. Dziennikarzy usiłowano wykorzystać dla własnych propagandowych celów. Armie wdrożyły w swych szeregach proces mobilizacji własnych korespondentów i fotoreporterów. I tak fotografie z okresu I wojny światowej, podlegając cenzurze wojskowej, przedstawiały zwykle wypoczętych, zadowolonych z życia żołnierzy. W wyniku przemyślanych działań, dopiero po zakończeniu wojny społeczeństwo zaczęło poznawać jej prawdziwy obraz. Sami bowiem szeregowi uczestnicy pozostawili po sobie obszerną dokumentację za sprawą firmy Kodak, która w ówczesnym czasie wprowadziła do produkcji tani, przenośny i prosty w obsłudze aparat fotograficzny (Grochmalski, 2001, s. 155).

W okresie międzywojennym profesja korespondentów wojennych stopniowo nabierała prestiżu. Przełom stanowiła możliwość podpisywania się fotografa swoim nazwiskiem przy własnych zdjęciach w prasie (Ibidem). Swoją zawodową pracę rozpoczęło w tym czasie wielu uznanych później fotoreporterów np. André Friedmann, który pod pseudonimem Robert Capa przeszedł do historii m.in. za zdjęcie padającego żołnierza wykonane podczas wojny domowej w Hiszpanii w latach 1936-1939.

Okres II wojny światowej przyniósł, na niespotykaną wcześniej skalę, mnogość technik dezinformacji oraz narodziny tzw. czarnej propagandy, której podstawą była totalna kontrola mediów². Prasa była bardzo istotna, jednakże nastąpił ogromny wzrost znaczenia radia w kontekście wykorzystywania go do celów propagandowych. Wskazuje się też, że władze zawierały często jawne sojusze z mediami, a zarówno brytyjscy, jak i amerykańscy dowódcy traktowali korespondentów bardziej jak sprzy-

${ }^{2} \mathrm{~W}$ tym czasie intensywnie działały ministerstwa propagandy, nazywane również ministerstwami informacji (Adamowski, 2007, s. 287-297). Pogłębiona analiza propagandy w czasie I i II wojny światowej: Jarecka, 2008. 
mierzeńca niż wroga. Niemniej, wymiar kontroli przekazu medialnego miał nieznany dotąd rozmach i inny charakter niż podczas I wojny światowej (Sekulski, 2012, s. 172). Popularna w Europie była myśl Josepha Goebbelsa, według którego korespondencja wojenna nie jest informacją, ale bronią (Hodalska, 2006, s. 47). Autorami relacji z frontu walk nadal byli lojalni korespondenci. Stosowana była rozległa cenzura, a liczne materiały filmowe o charakterze propagandowym wyświetlane były w kinach. Jako ciekawostkę warto dodać, że w końcowej fazie wojny, 150 brytyjskich i amerykańskich korespondentów wojennych pracowało na sześciu kontynentach na rzecz 278 mln czytelników (Hudson, Stainer, 1998, s. 82).

\section{Wojna w Wietnamie i jej konsekwencje w zakresie rozwoju kontroli nad mediami}

Powszechnie uznaje się, że w połowie lat sześćdziesiątych XX wieku, wraz z wojną w Wietnamie, nastąpił największy przełom w zakresie metod relacjonowania konfliktów zbrojnych. Łukasz Szurmiński wskazuje, że rozpoczęła się, na niespotykaną wcześniej skalę, ewolucja zachowania władz, zwłaszcza USA i Wielkiej Brytanii, w kontekście ich otwartości na dostęp dziennikarzy do linii frontu. $Z$ tego powodu istnieje możliwość wyróżnienia, w ramach relacji politycy-wojsko-dziennikarze, trzech modeli, które miały miejsce w historii konfliktów zbrojnych, począwszy od wojny w Wietnamie. Pierwszy zakłada pełną otwartość władz i wojska na dziennikarzy, drugi przewiduje całkowitą kontrolę nad przepływem informacji poprzez uniemożliwienie im dostępu do pola walki, a model trzeci - mieszany - uwzględnia dostęp do pola walki dla korespondentów, ale poddane jest to pewnym restrykcjom i pozostaje ściśle limitowane (Szurmiński, 2011, s. 78). Omówienie kolejnych, wybranych studiów przypadku pozwoli pokazać jak realizowano poszczególne modele oraz na jakie zmiany i udoskonalenia decydowali się decydenci wojskowi oraz władze USA.

Model pierwszy został zrealizowany w praktyce tylko raz w historii, kiedy w 1965 roku USA rozpoczęły interwencję zbrojną na terenie Wietnamu. Temu konfliktowi warto poświęcić nieco więcej uwagi gdyż narosło wokół niego wiele powierzchownych, stereotypowych ocen i uogólnień. Na początek warto zwrócić uwagę na sposób tworzenia przekazu medialnego. Wskazuje się często, że rozwój technologii sprawił, że 
śledzenie wydarzeń z frontu wojennego w Wietnamie było możliwe niemal „na żywo". W rzeczywistości, ze względu na duże koszty transmisji satelitarnej, dostarczenie materiału filmowego zabierało od jednego do dwóch dni. Niemniej, w porównaniu do okresu II wojny światowej, był to istotny postęp. W ten sposób z konfliktem w Wietnamie na stałe związał się termin ,pierwszej wojny telewizyjnej”. Prasa miała nadal ogromny wpływ na kształtowanie opinii publicznej, ale to na ekranie telewizorów aż $85 \%$ rodzin w USA posiadających odbiornik TV śledziło przebieg wydarzeń (Wolska-Zogata, 2012, s. 39). Wskazuje się często, że właśnie dzięki tej wojnie wzrosła rola telewizji jako głównego źródła informacji o toczących się konfliktach zbrojnych.

Należy pamiętać, iż wojna w Wietnamie była pierwszą, w której nie obowiązywała formalna cenzura. Co prawda, na początku konfliktu rozważano wprowadzenie cenzury wojskowej, lecz uznano ten pomysł za niepraktyczny. Przyjęto, że otwarta polityka informacyjna rządu jest słuszna, gdyż pozwala na budowanie obrazu skutecznych działań amerykańskiego wojska w Wietnamie. Departament Obrony USA wprowadził jedynie tzw. ground rules. Było to piętnaście zasad dotyczących szczególnie istotnych obszarów, takich jak lokalizacja i przemieszczanie się oddziałów, planowane operacje wojskowe itd. Dziennikarz, aby udać się do strefy walki, musiał uzyskać kartę akredytacyjną po podpisaniu wprowadzonych zasad. Łamiącym je groziło zawieszenie akredytacji lub anulowanie, a zdarzało się to niezmiernie rzadko. Reporterzy akredytowani przy amerykańskich oddziałach mogli udać się wszędzie i pisać o czym chcieli, co zresztą czynili (Ryżewski, 2009, s. 50-51). Co ciekawe, na początku wojny telewizyjne ekipy reporterów i fotoreporterów wojsko witało „z otwartymi rękami”. Żołnierze byli przekonani, że dzięki dziennikarzom świat zobaczy potęgę militarną USA. Wraz z upływem czasu i coraz większym zaangażowaniem USA w konflikt wzrastała liczba akredytowanych korespondentów z różnych państw, z 20 osób w 1964 roku do około 637 osób w 1968 roku (Fiedler, 2012, s. 148). Jednakże, jak zauważa Lech Ryżewski, amerykańscy dziennikarze nie znali na ogół miejscowego języka ani zwyczajów, stąd ich relacje sprowadzały się głównie do pokazywania obrazów prezentujących ,naszych chłopców w akcji”. Charakteryzowały się niedokładnością, wybiórczością tematów i często przesadzonymi komentarzami (Ryżewski, 2009, s. 47-48).

Konieczność rosnącego zaangażowania militarnego USA, ciągle wzrastająca liczba strat i ofiar oraz brak perspektyw na zakończenie konfliktu spowodowały, że wokół wojny w Wietnamie pojawiła się fala krytyki. 
Co prawda media nie podważały celowości tej wojny, ale pokazywały coraz częściej jej brutalność. Jak twierdzi Radosław Fiedler, odzwierciedlały one pogarszające się w USA nastroje społeczne, jak i te panujące pośród żołnierzy walczących w Wietnamie (Fiedler, 2012, s. 152). Momentem przełomowym dla postrzegania konfliktu były niekontrolowane relacje telewizyjne z podpalenia przez amerykańskie wojsko wioski Kam Nei w 1965 roku czy z ofensywy Tet rozpoczętej 1 lutego 1968 roku, będącej najkrwawszym epizodem wietnamskiej wojny (Wolska-Zogata, 2012 , s. 40). Taki wniosek jest do dziś powielany w literaturze przedmiotu. Jest on efektem badań, ale także dyskusji dziennikarzy, polityków i historyków, jakie odbywały się w latach 80 . w USA na temat roli mediów, a szczególnie telewizji podczas wietnamskiego konfliktu (Pietrygała, 2014, s. 76-79). Po zakończeniu wojny podniosły się bowiem głosy, że media wypaczyły prawdziwy obraz zdarzeń, fałszując i tendencyjnie akcentując fakty stwarzające wrażenie przegranej USA i wietnamskich sojuszników. Wskazywano, że dziennikarze opisywali wydarzenia w wysoce niepomyślnych i czasami wypaczonych słowach, a takie relacjonowanie przebiegu wydarzeń zrodziło w społeczeństwie amerykańskim poczucie, że wojna ta jest nie do wygrania (Ibidem, s. 78). Do grona krytyków zaliczali się przede wszystkim wojskowi i politycy, niepotrafiący ukryć rozczarowania antywojenną retoryką prasy i telewizji. Badacze twierdzą jednak, że wojna wietnamska ukazała przede wszystkim brak umiejętności prowadzenia polityki medialnej, gdyż administracje prezydentów Lyndona Johnsona i Richarda Nixona nie posiadały żadnej strategii współpracy z mediami (Fiedler, 2012, s. 155).

Trwający po wojnie ,syndrom wietnamski” istotnie wpłynął na amerykańską politykę oraz pokazał jak potężny wpływ na kształtowanie opinii publicznej ma telewizja (Ryżewski, 2001, s. 28-34). Wielokrotnie powtarzane jest twierdzenie, że ze względu na liczne przekazy telewizyjne, wojna w Wietnamie „weszła do living roomów Amerykanów” i to właśnie tam została przegrana. Codziennie bowiem około 60 milionów obywateli amerykańskich oglądało wieczorne dzienniki, w których relacjonowano wojenne wydarzenia (Jabłoński, 2006, s. 103). Beata Ociepka wskazuje, że omawiany konflikt był przełomowy pod trzema względami: technologicznym - po raz pierwszy telewizja miała tak potężny wpływ na opinię publiczną, polityczno-generacyjnym, gdyż pojawiła się grupa dziennikarzy, która krytycznie oceniała rząd amerykański oraz ze względu na otwarty dostęp korespondentów do działań na froncie. Takiego nie było nigdy wcześniej, a jak odwołuje się w swych rozważaniach Lech Ryżew- 
ski do książki Daniela C. Hallina The Uncensored War - zmiany w ukazywaniu przez stacje telewizyjne wizerunku wojny zaczęły ujawniać się jeszcze przed ofensywą Tet, w 1967 roku. Postępowały one stopniowo, wraz z pogłębianiem się podziałów politycznych w USA i wzrastaniem tempa walk w Wietnamie, by ulec przyśpieszeniu w czasie ofensywy Tet i następnych miesiącach (Ryżewski, 2001, s. 28-34; Hallin, 1986).

Nie da się zaprzeczyć, iż wojna w Wietnamie była pierwszym i zarazem ostatnim konfliktem, w czasie którego dziennikarze mogli pracować w warunkach olbrzymiej swobody. Miało to swoje konsekwencje w blokowaniu korespondentom dostępu do frontu walk podczas kolejnych wojen. Ponadto, każdy następny konflikt był już relacjonowany pod pewną kontrolą armii. Z kolei politycy i wojskowi rozpoczęli prace nad systemem zarządzania informacjami wojennymi, a przedstawiciele Departamentu Obrony USA podjęli kroki zmierzające do uniemożliwienia przedstawicielom mediów obecności na terenach objętych działaniami militarnymi (Szurmiński, 2011, s. 80-81).

Doświadczenia amerykańskie z Wietnamu zostały wykorzystane m.in. przez Brytyjczyków podczas wojny o Falklandy w 1982 roku. Wprowadzili oni model relacji wojsko-dziennikarze oparty na całkowitej kontroli nad przekazem medialnym ${ }^{3}$. Podobna sytuacja miała miejsce podczas amerykańskiej inwazji w Grenadzie w 1983 roku w ramach operacji Urgent Fury. Departament Obrony USA, przy aprobacie Departamentu Stanu USA, podjął decyzję, aby nie dopuszczać mediów do udziału w operacji, która rozpoczęła się 25 października 1983 roku. Głównodowodzący gen. John William Vessey wydał zgodę na lądowanie dziennikarzy na wyspie dopiero trzy dni później. W tym jednak czasie działania wojskowe dobiegły końca. Media nie miały szans relacjonować interwencji, a amerykańskie telewizyjne programy informacyjne pokazywały tylko filmy stworzone przez wojsko (Pękasa, 2008, s. 167-168).

3 Decydenci wojskowi ze względu na odległość i brak łączy satelitarnych mogli kontrolować przekazy medialne. Był to konflikt, z którego nie pokazywano wydarzeń na żywo. Armia brytyjska miała pełną kontrolę nad informacjami medialnymi, gdyż starannie wybrali korespondentów wojennych (29 osób), którzy płynęli na okrętach. Każdy posiadał cywilnego specjalistę od public relations, który został przydzielony przez Ministerstwo Obrony, aby nadzorować reporterów, a w razie potrzeby cenzurować ich materiały. Konflikt ten pokazał, że można odciąć dziennikarzy od miejsca gdzie on się toczy, a politycy doszli do wniosku, iż lepiej opierać się na propagandzie wojskowej (Węglińska, 2006, s. 136-139). 
Przez kolejne lata po inwazji w Grenadzie w USA powracały pytania dotyczące dostępu mediów do terenów operacji wojskowych. Pod naporem opinii publicznej, w 1984 roku, w Departamencie Obrony USA utworzono „Narodowy Zespół Mediów” (ang. Department of Defence National News Media Pool) z udziałem przedstawicieli mediów i wojska (Ibidem, s. 168). Podstawowym celem jego istnienia było stworzenie mniej restrykcyjnego systemu, który nie odcinałby dziennikarzy od strefy konfliktu. Nie udało się tego zrobić na oczekiwaną skalę nawet pięć lat później, kiedy 20 grudnia 1989 roku rozpoczęła się amerykańska interwencja w Panamie pod kryptonimem Just Case. Po doświadczeniach z Grenady, Dowództwo Wojsk USA lepiej zaplanowało relacje z mediami, gdyż korespondenci znaleźli się na miejscu już pięć godzin po rozpoczęciu operacji. Problem polegał jednak znów na tym, że większość z najważniejszych działań wojskowych była już zakończona. Dziennikarze zostali tego dnia zabrani na lot w kierunku centrum miasta Panama, jednak nie mieli możliwości bycia bliżej rejonu walk. Jedyne zatem co mogli zobaczyć to zniszczenia, dym i płomienie w kwaterze sił panamskich. Później zablokowano możliwość dostarczenia do USA filmów czy fotografii, na okres czterech dni, kiedy zaplanowano wykonanie strategicznych działań w ramach operacji wojskowej. W konsekwencji, w amerykańskich mediach nie ukazał się żaden materiał zawierający zdjęcia, które mogły prezentować zniszczenia na wyspie czy ofiary w ludziach od rozpoczęcia działań wojskowych (Szurmiński, 2011, s. 86-87).

Odwołując się zatem do wspomnianych w artykule modeli relacji pomiędzy wojskiem a dziennikarzami autorstwa Łukasza Szurmińskiego należy wskazać, że inwazja w Grenadzie, jak i operacja militarna w Panamie to przykłady drugiego modelu zakładającego całkowitą kontrolę nad przepływem informacji. Model trzeci, uwzględniający dostęp do pola walki dla korespondentów, lecz zarazem ograniczający go przez określone zasady współpracy, wystąpił po raz pierwszy w czasie I wojny w Zatoce Perskiej.

\section{Kontrola nad mediami i relacjonowanie wydarzeń podczas operacji „Pustynna Burza” w Zatoce Perskiej}

Na początku lat 90. prace amerykańskiego „Narodowego Zespołu Mediów" przyniosły efekt, jakim był wypracowany z trudem kompromis dotyczący relacji armia USA-dziennikarze. Stworzono swoiste novum 
w postaci news pool system ${ }^{4}$. Zastosowano go po raz pierwszy w czasie trwania operacji „Pustynna Burza” podczas I wojny w Zatoce Perskiej w 1991 roku. Jego głównym założeniem było zapewnienie dostępu do frontu w ramach kontrolowanych wypraw tylko wybranej i nielicznej grupie korespondentów, którzy mają przemieszczać się razem i pod ścisłym nadzorem specjalnej grupy oficerów prasowych. W tym celu utworzono media reporting teams, czyli zespoły mobilnych grup dziennikarzy (Ociepka, 2002, s. 142). Dodatkowo, w Dhahran w Arabii Saudyjskiej stworzono „Zespolone Biuro Informacyjne” (ang. Joint Information Bureau), w którym przebywała większość z ok. 1500 korespondentów zagranicznych relacjonujących ten konflikt zbrojny. Około $200 \mathrm{z}$ nich było częścią mobilnych zespołów. W ich ramach dziennikarze gromadzili swoje materiały audiowizualne. Następnie trafiały one do oficerów prasowych, a kolejno, dzięki wojskowym łączom, do różnych redakcji na świecie. Stworzone grupy reporterów musiały przestrzegać zasad ustalonych przez koalicję wojskową. W zamian otrzymywali oni ochronę ze strony przyporządkowanych oddziałów, a także byli informowani o przebiegu działań zbrojnych poprzez grupę półtora tysiąca specjalnych oficerów ds. public affairs (Szurmiński, 2011, s. 88).

Jedną z przyjętych reguł stosowanych podczas tej wojny był ścisły zakaz wstępu dla przedstawicieli mediów na linię frontu oraz do strefy bombardowań. Inną, nieprzekazywanie korespondentom informacji czy zdjęć dotyczących strat własnych, jak i po stronie przeciwnika (Jabłoński, 2006, s. 112-114). Tworzono bowiem obraz konfliktu z udziałem techniki wojskowej, która eliminuje niepotrzebne straty w ludziach, zwłaszcza wśród cywilów. Wojciech Jabłoński przywołuje stosowany ówcześnie mit wojny nowoczesnej o charakterze "chirurgicznym” (ang. pinpoint accuracy lub clear war). Śmiertelne ofiary miały być niemal wyłącznie po stronie wroga, cywile mieli pozostać bezpieczni, a stosowany przez wojskowych żargon np. ,precyzyjne uderzenia”, ,inteligentne bomby”, był używany także przez wielu dziennikarzy amerykańskich. Po latach okazało się, że tylko ok. $10 \%$ pocisków wystrzelonych przez aliantów było dokładnie namierzanych na cel(Ibidem, s. 117-118). Do dziś brakuje też dokładnych danych na temat ofiar - cywilów. Ocenia się jedynie, że podczas I wojny w Zatoce Perskiej zginęło około 100 tysięcy Irakijczyków. Niedostępne są także raporty o stratach po stronie armii USA (Ibi-

${ }^{4} \mathrm{~W}$ literaturze przedmiotu pojawiają się także określenia press pool system lub media pool system. 
dem, s. 120). Stąd zdaniem W. Jabłońskiego, kreowanie tego mitu należy uznać za niewypał i źródło sytuacji kryzysowych w okresie powojennym, gdy dokonywano podsumowań (Ibidem, s. 123-124). Z kolei Magdalena Hodalska twierdzi, że szereg rozwiązań mających kontrolować przepływ informacji i audiowizualnych treści spowodował, że w pewnym stopniu Departament Obrony i Departament Stanu USA przejęły rolę korespondenta wojennego. Filmy były bez krwi, rannych czy zwłok, a te same sekwencje pojawiały się we wszystkich telewizjach na świecie. Materiały prasowe pokazywały np. ataki lotnicze wojsk USA i ich sukcesy, pomijając pomyłkowe bombardowania celów cywilnych. Służby informacyjne rządu USA chętnie dostarczały też atrakcyjne informacje na temat sprzętu bojowego państw koalicji, co dziennikarze wykorzystywali w swoich materiałach (Hodalska, 2006, s. 48-52). Co więcej, by zdobyć poparcie amerykańskiej opinii publicznej dla decyzji prezydenta USA o odparciu inwazji Iraku na Kuwejt, wynajęto firmę PR - Hill\&Knowlton, która przygotowała serię audycji pokazujących okrucieństwa żołnierzy Saddama Husajna wobec ludności cywilnej. Stworzone filmy bardzo często były zmanipulowane na potrzeby polityczne, ale miały spory zasięg. Jeden z nich, z udziałem córki ambasadora Kuwejtu w Waszyngtonie, został wyemitowany przez niemal siedemset stacji telewizyjnych na świecie (Kunczik, Zipfel, 2000, s. 281-282). Jak podkreśla Rafał Pękasa, amerykańskie władze i wojsko dbały o bezpieczeństwo planów wojskowych, przekonanie świata o legitymizacji działań wojennych, nienarażanie koalicji na informacje godzące w jej spójność i zapewnienie poparcia społeczeństwa (Pękasa, 2008, s. 169-170).

Niewielu dziennikarzy podczas tego konfliktu przedostawało się do Iraku „na własną rękę” lub decydowało się działać samemu. Armia amerykańska miała przepływ informacji pod tak dobrą kontrolą, że twórcy dziennika „Frankfurter Allgemeine Zeitung” w styczniu 1991 roku napisali, iż ,jeszcze nigdy tak wielu dziennikarzy, przy użyciu tak wielu słów i obrazów nie przekazało tak skąpych treści” (Kunczik, Zipfel, 2000, s. 279). Jednakże, korespondentów zebranych $\mathrm{w}$ ramach media reporting teams nie zawsze dało się upilnować wedle przyjętych założeń w zakresie tworzonego przekazu medialnego. Byli tacy jak Peter Arnett - reporter CNN, który pozostał w Bagdadzie podczas ostatniej fazy bombardowania miasta, przekazując na żywo, z przenośnej anteny satelitarnej, obrazy stolicy z okna hotelowego pokoju. Stworzył on też reportaże ukazujące ofiary wśród ludności cywilnej czy przeprowadził wywiad z Saddamem Husajnem. Jednakże to jego całonocna relacja $z$ bombardowania Bagdadu powtarzana była przez 
stacje na całym świecie i przyniosła CNN renomę i rekordową oglądalność (Dwornik, 2017). Istotnym wydarzeniem było też sfotografowanie drogi nr 80 pomiędzy Kuwejtem a Basrą w Iraku, nazywaną później ,autostradą śmierci”. Odbyło się to na trasie do stolicy Kuwejtu po zajęciu miasta przez siły koalicji międzynarodowej. Na drodze doszło do rzezi irackich wojsk oraz cywilów wycofujących się z Kuwejtu w nocy z 26 na 27 lutego 1991 roku (Kunczik, Zipfel, 2000, s. 280-281). W ciągu dwóch dni zniszczono około 2000 irackich czołgów i pojazdów opancerzonych, a do mediów wypłynęło wiele drastycznych zdjęćs

W porównaniu do wojny w Wietnamie, podczas I wojny w Zatoce Perskiej, po raz pierwszy w historii, przekaz satelitarny umożliwił real time reporting, czyli relacjonowanie wydarzeń w czasie rzeczywistym dla milionów odbiorców telewizji na całym świecie. Wskazuje się, iż stanowiło to początek nowego sposobu uprawiania dziennikarstwa, rozwijanego w kolejnych konfliktach. Dyskusja wokół relacjonowania tej wojny w największej mierze skupiła się na CNN, która w czasie jej trwania docierała do około stu milionów widzów w 103 państwach. Stacja ścigała się z innymi telewizjami w zakresie nowych informacji z rejonu Zatoki Perskiej, ale zapewniła sobie przewagę $\mathrm{w}$ transmitowaniu wojny poprzez wynajęcie za 15 tysięcy dolarów tygodniowo, dodatkowego systemu łączy telefonicznych (Ociepka, 2002, s. 142-143). Jej rola podczas tego, jak i kolejnych konfliktów, także w kontekście polityki i komunikacji międzynarodowej doczekała się nawet ujęcia w ramy koncepcji naukowej nazwanej ,efektem CNN"6.

28 lutego 1991 roku prezydent George H. W. Bush ogłosił zwycięskie zakończenie wojny w Zatoce Perskiej i wyzwolenie Kuwejtu, podkreślając to wydarzenie jako przełamujące ,syndrom wietnamski” (Wolska-Zogata, 2012, s. 41). Na skutek politycznej decyzji prezydenta Stanów Zjednoczonych, wojska lądowe koalicji nie podjęły już próby zajęcia stolicy Iraku. Wydano rozkaz przerwania działań, a Saddam Husajn zaakceptował warunki rozejmu. Okazało się też, że idea mobilnych zespołów korespondentów tylko do pewnego stopnia przyniosła oczekiwany suk-

${ }^{5}$ Co ciekawe, w 2013 r. opisano w polskich mediach, że pozostałości samochodów, czołgów, maszyn itd. znajdują się w podobnym stanie, w jakim porzucono je w 1991 roku (Kiszniewski, 2013).

${ }^{6}$ Określa ona ogromną rolę mediów w zakresie informowania obywateli, ale także wpływ relacji medialnych na polityków, działania dyplomatyczne oraz politykę zagraniczną państw. Zjawisko to najczęściej rozpatrywane jest z perspektywy wpływu kanału CNN na decyzje przywódców USA (Robinson, 2005). 
ces. Reporterzy narzekali na nadmierną cenzurę oraz zdanie się na łaskę lub niełaskę dowódców wojskowych, którzy najczęściej traktowali ich jako przeciwników, a sami przesadnie utajniali wiele spraw związanych z działaniami militarnymi. Z kolei przedstawiciele wojsk zwracali uwagę głównie na niespodziewaną dynamikę informacji, zapotrzebowanie na nie przez dziennikarzy oraz brak środków transportu, które mogłyby być wydzielone do obsługi mediów (Pękasa, 2008, s. 169).

\section{Podsumowanie}

Jak pokazuje historia, wraz z każdym kolejnym konfliktem zbrojnym, korespondenci wojenni byli coraz bardziej narażeni na polityczne naciski, a także musieli zmagać się z bezpośrednią lub pośrednią formą cenzury wojskowej. W uwarunkowaniach relacji politycy-wojsko-dziennikarze można zaobserwować, że charakteryzowana ewolucja kontroli nad mediami w omawianych konfliktach dokonuje się przede wszystkim wraz $\mathrm{z}$ konkretnymi zmianami w metodach zarządzania komunikacją, które były stosowane przez wojskowych oraz władze USA, głównie w zakresie kontroli dostępu do informacji, jak i do pola walki. Podstawowym celem stała się neutralizacja niewygodnych wiadomości, kontrolowanie ich przepływu, jak i samych korespondentów wojennych oraz promowanie materiałów o charakterze propagandowym. Reporterzy wojenni, którzy podróżowali razem z żołnierzami byli zawsze w pewien sposób zależni od armii, choć z drugiej strony, wojskowi zaczęli stanowić dla dziennikarzy istotne źródło informacji ${ }^{7}$.

Zauważalnie, od czasu wojny w Wietnamie, współpraca pomiędzy politykami USA, jak i wojskiem a przedstawicielami mediów masowych podlegała wielu modyfikacjom, które skategoryzować można w trzech wspomnianych modelach relacji. USA starały się unikać błędów, jakie popełniono w Wietnamie w relacjach z mediami, choć nie było to od razu możliwe. Wojna w Wietnamie, określana jako militarne zwycięstwo przy medialnej klęsce, dała początek procesom mediatyzacji konfliktów zbrojnych, których rozwój, wraz z nowymi mediami, obserwujemy współcześnie. Historia korespondencji wojennej i ewolucji sposobów tworzenia przekazów medialnych oraz ich znaczenia pozwalają według Tomasza

${ }^{7}$ Warto podkreślić, że towarzyszenie przez korespondentów siłom zbrojnym miało także swoje konsekwencje w zakresie ich ochrony i statusu prawnego w świetle prawa międzynarodowego (Grządzielski, 2018, s. 65-80). 
Gobana-Klasa wyróżnić trzy fale mediatyzacji wojny. Pierwsza rozpoczęła się wraz z wojną krymską w 1853 roku i pojawieniem się w jej trakcie reporterów wojennych. Początek drugiej datowany jest na okres wojny w Wietnamie, a umocniła ją operacja „Pustynna Burza” w 1991 roku kiedy telewizja rozpoczęła na masową skalę wykorzystywanie łączy satelitarnych, dostarczając na żywo transmisje ze stref konfliktu. Trzecia fala mediatyzacji wojny odnosi się do świata internetu i mediów społecznościowych (Goban-Klas, 2011, s. 328-332).

Jak wykazano w powyższej analizie, przekazywanie wiadomości z rejonów działań zbrojnych ulegało istotnym zmianom, jak i sama organizacja pracy korespondentów wojennych. Nastąpił znaczący rozwój środków komunikowania masowego oraz technicznych możliwości przemieszczania się reporterów na terenach walk. Niezmienny jednak pozostał problem m.in. kształtu relacji pomiędzy mediami masowymi a władzą i wojskiem oraz kwestii dostępu do informacji. Podczas operacji „Pustynna Burza” w Zatoce Perskiej politycy i wojskowi, przy wykorzystaniu legalnie dostępnych środków, rozpoczęli kolejny proces wpływania na obraz konfliktu zbrojnego w mediach masowych, a zarazem w społecznej świadomości odbiorców przekazu medialnego. Istniało przekonanie, że przekucie sukcesów militarnych w korzyści o charakterze politycznym uzależnione jest w dużej mierze od tego w jaki sposób zostaną one przedstawione w mediach i jaki stosunek do konfliktu przyjmie społeczeństwo amerykańskie. Relacje medialne stały się zatem czynnikiem ingerującym $\mathrm{w}$ proces kształtowania się postaw w ramach opinii publicznej, a w konsekwencji w przebieg podejmowania decyzji politycznych.

\section{Bibliografia}

Adamowski J. W. (2007), Media masowe a wojna. Doświadczenia brytyjskie z okresu I i II wojny światowej, w: Wojna w mediach, red. W. Piątkowska-Stepaniak, B. Nierenberg, Wyd. Uniwersytet Opolski, Opole.

Bednarek Z. (2018), Wzajemne relacje dziennikarstwa wojennego i stosunków międzynarodowych - przyczyny, mechanizmy, konsekwencje, „Acta Universitatis Lodziensis. Folia Litteraria Polonica”, nr 5.

Dwornik M. (2017), Peter Arnett. Reporter wojenny, groźniejszy niż batalion Wietkon$g u, \quad$ https://reporterzy.info/3529, peter-arnett-reporter-wojenny-grozniejszyniz-batalion-wietkongu.html, 16.12.2019.

Fiedler R. (2012), Obraz wojny w Wietnamie w optyce amerykańskich korespondentów wojennych, w: Korespondent wojenny. Etyka, historia, wspótczesność, 
red. K. Wolny-Zmorzyński, J. Snopek, W. Furman, K. Bernat, Wyd. Wyższej Szkoły Ekonomii i Prawa im. prof. Lipińskiego, Kielce.

Goban-Klas T. (2011), Wartki nurt mediów, Wyd. Prac Naukowych Universitas, Kraków.

Grochmalski P. (2001), Korespondent wojenny, w: Media i polityka, red. J. Sobczak, Wyd. Likon, Poznań-Września 2001.

Grządzielski K. (2018), Legal status and scope of protection of war correspondents in armed conflicts in the light of international law - review of selected legal acts, ,Refleksje”, nr 18.

Hallin D. C. (1986), The uncensored war: the media and Vietnam, Wyd. Oxford University Press, New York-Oxford.

Hodalska M. (2006), Korespondent wojenny. Ofiarnik i ofiara we współczesnym świecie, Wyd. Uniwersytet Jagielloński, Kraków.

Hudson M., Stainer J. (1998), War and the Media, Wyd. New York University Press, New York.

Jabłoński W. (2006), Kreowanie informacji. Media relations, Wyd. Naukowe PWN, Warszawa.

Jarecka U. (2008), Propaganda wizualna stusznej wojny. Media wizualne XX wieku wobec konfliktów zbrojnych, Wyd. IFiS PAN, Warszawa.

Kiszniewski A. (2013), Cmentarzysko stalowych duchów pozostałościa po I wojnie $w$ Zatoce Perskiej, http://technowinki.onet.pl/cmentarzysko-stalowychduchow-pozostaloscia-po-i-wojnie-w-zatoce-perskiej/r49ky, 29.12.2019.

Klepka R. (2016), Wojna w mediach: wybrane zagadnienia dotyczace relacjonowania konfliktów zbrojnych, „Wojny i konflikty. Przeszłość, teraźniejszość, przyszłość", nr 1.

Kunczik M., Zipfel A. (2000), Wprowadzenie do nauki o dziennikarstwie i komunikowaniu, tł. J. Łoziński, W. Łukowski, Wyd. Scholar, Warszawa.

Ociepka B. (2002), Komunikowanie międzynarodowe, Wyd. Astrun, Wrocław.

Pękasa R. (2008), Wojna - media i propaganda, „Doctrina. Studia Społeczno-Polityczne", nr 5.

Pietrygała R. (2014), Rola mediów w konflikcie wietnamskim, „Ogrody Nauk i Sztuk”, nr 4.

Robinson P. (2005), The CNN Effect: The Myth of News, Foreign Policy and Intervention, Wyd. Routledge, London-New York.

Ryżewski L. (2001), Wietnam na szklanym ekranie: ofensywa Tet i amerykańskie media, „Mówią Wieki”, nr 4.

Ryżewski L. (2009), Obraz komunistycznej ofensywy Tet w amerykańskich mediach, „Studia Medioznawcze”, nr 1.

Sekulski H. (2012), Korespondencja wojenna - między słowem a obrazem, w: Korespondent wojenny. Etyka, historia, wspótczesność, red. K. Wolny-Zmorzyński, J. Snopek, W. Furman, K. Bernat, Wyd. Wyższej Szkoły Ekonomii i Prawa im. prof. Lipińskiego, Kielce. 
Szurmiński Ł. (2011), Media na wojnie - modele relacji wojsko-dziennikarze na przykładzie konfliktów zbrojnych w XX i XXI wieku, w: Manipulacja w mediach. Media o manipulacji, red. T. Gackowski, J. Dziedzic, Wyd. Aspra, Warszawa.

Węglińska A. (2006), Media w sytuacji konfliktu, „Rocznik Bezpieczeństwa Międzynarodowego", vol. 1.

Wolska-Zogata I. (2012), Media i wojna. Między informacją a propaganda, „Zeszyty Naukowe WSOWL", nr 3.

\section{The evolution of control over mass media in the context of creating media coverage during selected armed conflicts before the Second Gulf War}

\section{Summary}

The armed conflicts in the 20th century have become media events, and the way how journalists reported them, largely created their image in the eyes of the international community. War coverage has become an instrument for influencing the course of conflicts as well as military and political decisions according to manage media and information during their duration. In this context, the purpose of the article is to analyse the evolution of forms of media control, their determinants and consequences. The impact of war reporting on selected armed conflicts will also be indicated. In addition, changes in relations between politicians and military officers and mass media representatives will be also taken into consideration. The time range of the article includes examples of conflicts in which key changes occurred in the context of the issues discussed in the article, from the Vietnam War to the first Gulf War.

Key words: armed conflict, war, media, war correspondent, mediatization of armed conflicts, war coverage

\section{Informacja o autorze}

Krzysztof Grządzielski [krzysztof.grzadzielski@amu.edu.pl] - dziennikarz, doktorant na Wydziale Nauk Politycznych i Dziennikarstwa UAM w Zakładzie Dziennikarstwa. Absolwent studiów magisterskich tego wydziału na kierunku stosunki międzynarodowe oraz dziennikarstwo i komunikacja społeczna. Jego zainteresowania koncertują się wokół mediów lokalnych, radiofonii oraz historii korespondencji wojennej, mediatyzacji konfliktów zbrojnych, a także zagadnień związanych z media relations i komunikowaniem za pomocą nowych mediów. 